\title{
Public debt crisis, austerity and deflation: the case of Greece
}

\author{
Marica Frangakis* \\ Nicos Poulantzas Institute, Athens, Greece**
}

Greece is the country in which the eurozone's public debt crisis began in late 2009. The policy response of the EU elites was to provide financial assistance on condition that a strict austerity-cum-deregulation policy is applied under the watchful guidance of the European Commission, the European Central Bank and the IMF (the so-called Troika). Five years later, the country is in an economic, social and political limbo, as a debtdeflation process has set in. Greece, however, is not a special case. Rather, it illustrates the failures of the prevailing economic and political orthodoxy in the EU. At best, it can serve as an example of the cost of ignoring the lessons of the 1930s Great Depression.

Keywords: austerity, eurozone crisis, public debt, deflation, depression

JEL codes: E310, E650, E660

\section{INTRODUCTION}

It is an observed fact that developments in economic thought tend to follow economic developments. This is especially true of economic crises, which 'can sometimes trigger enormous change, with regard to both economic theory and the politics of governance' (Palley et al. 2012, p. 1). For example, although under-consumption is an old concept in economics going back to the sixteenth century, it was against the experience of the 1929 Crash and the 1930s Great Depression that the economic and social implications of falling incomes and prices were discussed and new analytical tools conceived, challenging the economic dogmas of the time and replacing them with a new corpus of ideas and principles. Unfortunately, the theoretical insights gained over the 1930s Great Depression were lost sight of in the latter part of the twentieth century, as the prevalent paradigm shifted back to the orthodoxy which Fisher, Keynes and Kalecki had challenged, to name but three thinkers of the time who made major contributions to understanding the then prevailing economic, social and political conditions.

The misconceptions, gaps and weaknesses of present-day mainstream economics were revealed by the 2007/2008 global financial crisis and the ensuing economic crisis. However, following the initial panic, economic policy reverted to the pre-crisis orthodoxy, thus ignoring the lessons of the 1930s. This is especially true of the EU,

* I would like to thank two anonymous referees for their valuable comments. Of course, all errors remain mine.

** Marica Frangakis is an independent researcher (frangaki@ otenet.gr; http://academia.edu). She is a member of the Board of the Nicos Poulantzas Institute and a member of the Steering Committee of the EuroMemo Group (http://euromemo.eu). 
the response of which has been a combination of austerity and deregulation on the one hand, and financial policy reform at a snail's pace on the other.

As a result, much intellectual energy needs to be spent on revisiting ideas and theories developed against the background of the Great Depression and examining their relevance today. It is in this spirit that the present article is written. Its objective is to examine the current Greek crisis through the lens of debt-deflation dynamics within the framework of EU economic policy.

The structure of the article is as follows. Section 2 discusses EU economic policy and its crisis response; the centrality of austerity is highlighted. Section 3 examines the public debt crisis in Greece under conditions of austerity, with reference to the debtdeflation mechanism. Section 4 is an epilogue, by way of summarizing and concluding.

\section{EU ECONOMIC POLICY AND CRISIS RESPONSE: FROM WAGE AND PRICE RESTRAINT TO AUSTERITY}

\subsection{The framework of EU economic policy}

Wage and price restraint is inherent in EU economic policy. The single currency edifice rests on a narrowly defined range of fiscal indicators and an equally narrowly defined monetary policy, focusing on inflation-targeting. The member states that do not belong to the eurozone emulate the benchmarks set for the latter. Thus, the differing levels of productivity, growth and employment across the EU member-states are by design outside the core policy concerns. As a result, wages constitute the main adjustment mechanism in EU economic relations.

More specifically, the benchmarks set by the Stability and Growth Pact (SGP) limit the fiscal deficit to 3 per cent and the public debt to 60 per cent of GDP, while the European Central Bank is entrusted with keeping inflation 'below but close to 2 per cent' and not lending to European public authorities of any kind, level, etc. The inefficiency of the euro architecture became evident in the early 2000s and the dot.com bubble, when the SGP was violated by Germany and France among others, and declared 'stupid' by the then President of the European Commission, Romano Prodi. ${ }^{1}$ As a result, certain aspects of the SGP were relaxed, although its essence remained intact. ${ }^{2}$

In the course of the 1990s and 2000s, the EU radically liberalized its financial system, promoting the integration of the financial markets with great enthusiasm. In fact, by the mid 2000s, the EU authorities boasted that the money market and the government bond market were completely integrated. ${ }^{3}$ Some years later, both markets seized up as the financial crisis migrated from the USA to Europe. Only then did the implications of the lack of provisions, or indeed concern, for financial stability become clear. ${ }^{4}$

1. http://www.telegraph.co.uk/finance/2830598/Euro-Stability-Pact-is-stupid-says-Prodi. html.

2. For example, certain types of public expenditure might justify a 'small overshoot' of the limit on the deficit/GDP ratio, while additional time may be allowed for the correction of an excessive deficit when growth is slow. See Frangakis (2006) for an appraisal of the changes to the Stability and Growth Pact introduced in 2005.

3. This is a claim regularly made in the annual Financial Integration Reports of the European Commission prior to the crisis.

4. For a detailed critique of the EU financial integration policy, see Grahl (2009). 
Until that time, however, the increasingly financialized environment of the EU provided the missing link in reconciling the different levels of productivity and competitiveness within the EU and especially the eurozone. The less competitive member states in terms of unit labour costs borrowed at a low interest rate from the financial institutions of the more competitive ones. The latter were happy to lend, as their domestic market did not provide an adequate outlet. Thus, the export-led model of the largely Northern European countries was combined with the debt-led model of the mainly Southern European countries to produce the imbalances that later became evident (Stockhammer 2012).

This happy state of affairs lasted until the outbreak of the crisis; that is, until the late 2000s. The imbalances upon which the single currency rested became only too clear, as the financial crisis fed into an economic crisis, which in turn inflated the public deficit and debt of the EU member states. Although this chain of events is historically familiar, given the record of capitalist crises, it caught the EU authorities unawares and unprepared to deal with it. However, as the early panic of the financial crisis subsided, the EU authorities declared the crisis at an end in early 2009 and reverted to the main tenets of the pre-crisis economic policy, with an added twist. The contractionary fiscal policy of the SGP became even more so. Austerity had arrived in Europe. This was entrenched in new fiscal policy measures, as well as in the 'Economic Adjustment Programmes' signed by indebted member states, such as Greece.

In particular, the revised EU fiscal policy rules introduced more stringent requirements, sanctions and procedures. ${ }^{5}$ For example, a new benchmark limits public expenditure growth to that of potential GDP, which is however not an observable variable; public debt in excess of the 60 per cent of GDP limit must be reduced at a rate of 1/20th per year; sanctions are imposed automatically unless a qualified majority in the Council votes against them (reverse qualified majority voting); the observance of the EU fiscal policy framework is monitored through enhanced surveillance rules, while the European Court of Justice may impose a financial sanction ( 0.1 per cent of GDP) on a member state, if it fails to transpose the new fiscal rules in national law through preferably constitutional provisions.

By contrast, financial policy reform, deemed necessary in the aftermath of the crisis, is proceeding in a slow, piecemeal fashion, while major issues such as the size and interconnectedness of the EU financial institutions are not addressed. In this way, the inefficiency and class bias inherent in the EU economic policy framework were extended to its crisis response. Furthermore, they were compounded by the theoretical misconception of the crisis and the ideological bias of the economically and politically strongest member state, Germany, against inflation.

\subsection{Austerity: theory and morality}

The response of the EU to the financial crisis was to provide generous, unconditional support to its banks. Over the period 2008-2012, approximately 40 per cent of EU GDP was devoted to rescuing the financial system (European Commission 2012). Such rescues were in blatant violation of the no-bail-out clause of the 2005

5. The post-crisis EU fiscal framework comprises, in addition to the SGP, the so-called 'six pack' (five regulations and one directive), the 'two pack' (two regulations) and the Fiscal Compact, which is contained in the intergovernmental Treaty on Stability, Coordination and Governance. 
Memorandum of Understanding on crisis management in the EU financial sector, as well as of the EU competition policy more generally. ${ }^{6}$

Furthermore, the support extended to the banks was financed from the member states' individual budgets, thus exacerbating the effect of the crisis on public finances. As might be expected, this led to increased public deficits and debt across the EU, which alerted the EU authorities. Accordingly, the narrative of the crisis advanced by the EU elites shifted from finance to fiscal profligacy and lack of competitiveness, thus deflecting the pressure for financial reform and redirecting public anger about the crisis against particular countries and governments. This narrative justified the ever-tighter fiscal policy implemented both on the EU level and in individual member states, thus providing the theoretical underpinning and moral basis for the EU austerity-led crisis response. However, it is problematic both in theoretical and in moral terms.

Theoretically, relying on generalized austerity to deal with a recession commits the error of the fallacy of composition, which is tantamount to overlooking the Keynesian savings paradox. In particular, whereas a household may well wish to reduce its debt exposure during a recession, the same cannot be said of the aggregate of households, far less of the government. Indeed, if all households reduce their consumption in order to pay off their debts, the government needs to make up the fall in demand by increasing its own spending, so as to avoid the recession becoming deeper. Thus, ignoring the Keynesian savings paradox implies that increasing aggregate savings in a recession is harmful for the economy. However, this is precisely what generalized austerity is about!

The moral basis of the EU austerity drive goes even further, insofar as it draws a parallel between those residing in Southern Europe and the proverbial 'Swabian housewife' (Schwäbische Hausfrau), who manages her household with prudence, setting an example for others. For example, Wolfgang Schauble, Germany's federal minister of finance, has stated in plain terms that austerity is the 'only cure for the eurozone'. In particular,

the recipe is as simple as it is hard to implement in practice; western democracies and other countries faced with high levels of debt and deficits need to cut expenditures, increase revenues and remove the structural hindrances in their economies, however politically painful. (Schauble 2011)

Analytically, the moral basis of austerity conveniently ignores the fact that in a monetary union, competitiveness is a relative notion. If all member states restrain wages at the same time, the result will be a 'beggar thy neighbour' race to the bottom and a frantic search for export markets. After all, in the early 2000s Germany was able to restore its competitiveness by repressing wages while the other eurozone member states provided the spending power that supported German exports. However, in the present crisis, Germany is not willing to reciprocate, preferring instead a competitive wage-price process. The explanation for Germany's stance lies also in its ideological bias against inflation, in spite of the fact that the country has known painful bouts of deflation in the not too distant past. ${ }^{7}$

6. The $2005 \mathrm{MoU}$ includes arrangements for the development of contingency plans for the management of crisis situations, along with stress-testing and simulation exercises and an explicit statement that it should not be construed as representing an exception to (i) the principle of the firm's owners'/shareholders' primary financial responsibility; (ii) the need for creditor vigilance; and (iii) the primacy of market-led solutions when it comes to solving crisis situations in individual institutions.

7. A similar moralistic stand was taken during the 1930s Great Depression by the 'liquidationists'; that is, those supporting the liquidation of large segments of the economy in the name of the revitalization of the productive forces, which included Friedrich Hayek, Lionel Robbins and Joseph Schumpeter. 
Overall, the theoretically fallacious and the morally/ideologically biased understanding of the crisis is weakening the eurozone and the EU more generally, as growth remains subdued, turning negative in certain areas, while unemployment has reached a historic high. For example, in 2013, real GDP was stagnant in the EU on average ( 0.0 per cent) and it declined in the eurozone ( -0.5 per cent $)$, while in 10 out of 28 countries of which 8 belong to the eurozone, it registered negative values (European Commission 2014). In 2013, unemployment reached 10.8 per cent of the labour force in the EU on average and 11.9 per cent in the eurozone, while in 9 countries it was significantly greater than average (from 14.2 per cent in Slovakia to 27.5 per cent in Greece). Furthermore, the rate of inflation was very low in most countries in 2013, while it is estimated to have turned negative in 2014. In particular, in 2013 inflation was equal to 1.5 per cent in the EU on average and 1.4 per cent in the eurozone, expected to slip down to 0.6 per cent and 0.5 per cent respectively in 2014, while negative values were registered in Greece ( -0.9 per cent in 2013 and -1 per cent in 2014), Spain (1.5 per cent and -0.1 per cent), Cyprus ( 0.4 per cent and -0.2 per cent), Slovakia ( 1.5 per cent and -0.1 per cent) and Bulgaria ( 0.4 per cent and -1.4 per cent). Disinflation and deflation appear to have set in throughout the EU and especially in Central and Southern Europe.

\subsection{Monetary policy and austerity}

As the sole objective of the European Central Bank is that of maintaining inflation 'below but close to 2 per cent', it has had to improvise since the early stages of the financial crisis in order to prevent the monetary transmission mechanism from breaking down as the interbank market seized up in late 2007. Such unconventional measures have included purchases of limited amounts of government bonds in the secondary market (Securities Market Programme 2010/2011), relaxing the rules on collateral, providing long-term financing to the banking sector under the ECB's Long Term Refinancing Operations (LTRO 2011 to present) and its Targeted LTRO (2014-2018), reducing its main refinancing operations rate to 0.05 per cent in September 2014, a historic low, announcing its intention to do 'whatever it takes' to stem financial speculation in the secondary government bond market (Outright Monetary Transactions, 2012) and eventually undertaking quantitative easing, or an 'expanded asset purchase' programme, encompassing the existing purchase programmes for asset-backed securities and covered bonds (January 2015). In particular, the ECB will buy bonds issued by eurozone governments, agencies and European institutions in the secondary market against central bank money. The combined monthly asset purchases are targeted at $€ 60$ billion, to be carried out until at least September 2016.

It is worth noting that the ECB's assistance - including its latest 'bazooka' - has been mainly addressed to the European banking sector, while that addressed to the eurozone governments via the secondary bond market is conditional on the implementation of austerity measures. Schiaffino calls this the 'ECB solution ... [which is] designed to save every euro from households, firms and government and reassign it to debt payments' (Schiaffino 2013, p. 460).

Thus, while the ECB has periodically eased liquidity pressures, it has not deviated from the central EU policy line of austerity in dealing with the crisis. Not surprisingly, its escalating monetary policy offensive has so far failed to stop the slide of the eurozone into stagnation, nor of the average inflation rate to below 2 per cent. Furthermore, the ECB is running out of options, in view of the fact that further reductions in its lending rate are bound to be ineffective, as this is already close to the zero bound. 


\section{THE CASE OF GREECE}

\subsection{Revisiting debt-deflation depression: some theoretical considerations}

In this section, we discuss certain elements of the theory of debt-deflation, which we consider as essential for the understanding of the forces at work in the Greek case. The term was popularized by Irving Fisher, who put forward the 'Debt-Deflation Theory of the Great Depression' in a seminal 1933 article (Fisher 1933). He focused on the financial crash, the devastating effects of a downward spiral linking the fall in assets and in goods prices, the process of deleveraging by households and firms and the ensuing contraction of economic activity with its disastrous social effects. The chain of consequences of a debt-deflation dynamic process is as follows:

- Declining prices give rise to expectations of a further drop. This provides consumers with the incentive to postpone purchases. As a result, aggregate demand falls, putting further downward pressure on prices. Also, the foreign-exchange value of the currency hardens, thus exacerbating the situation via the trade channel.

- Since public and private debts are fixed nominally, declining prices increase their real value. This induces households and businesses to reduce their consumption of goods and services in order to spend a higher proportion of their income on servicing their debt. To the extent that the government emulates household behaviour, the debt-deflation downward spiral is intensified.

- Furthermore, households and businesses are driven to distress selling in order to service their debts, thus driving asset prices down. Where a government opts for the privatization of public assets in order to repay its creditors, it adds to the downward pressure on asset prices.

- The greater the decline in asset prices, the greater the fall in the net worth of businesses, precipitating bankruptcies. Together with the drop in aggregate demand, this leads to a decline in profit and a reduction in output and employment.

- Pessimism and loss of confidence become the order of the day, leading to the hoarding of cash.

- Under these circumstances, while nominal interest rates decline, real interest rates rise, impeding the overcoming of the debt-deflation dynamics.

In observing this chain of events, Fisher noted a 'great paradox', whereby 'the more the debtors pay, the more they owe' (ibid., p. 344). Hence, Fisher concluded that the 'natural' way out of deflation propagated by the conventional wisdom of his time was 'via needless and cruel bankruptcy, unemployment and starvation' (ibid., p. 346). He rejected this prospect, arguing that 'great depressions are curable and preventable through reflation and stabilisation' (ibid., p. 350).

Fisher's 'great paradox' echoes Keynes's 'savings paradox', whereby ${ }^{8}$

although the amount of (an individual's) own saving is unlikely to have any significant influence on his own income, the reactions of the amount of his consumption on the incomes of others makes it impossible for all individuals simultaneously to save any given sums. Every such attempt to save more by reducing consumption will so affect incomes that the attempt necessarily defeats itself. (Keynes 1936 [2003], ch. 7, p. 84).

8. This is tantamount to the 'fallacy of composition', which holds that what is true of the parts must be true of the whole. 
The deleterious effects of the debt-deflation process were explicitly recognized by Keynes, who, in discussing the Great Slump of 1930, noted the following:

Thus neither the restriction of output nor the reduction of wages serves in itself to restore equilibrium ... every fall of prices increases the burden of this [post-World War I] debt, because it increases the value of the money in which it is fixed ... In such a situation it must be doubtful whether the necessary adjustments could be made in time to prevent a series of bankruptcies, defaults, and repudiations which would shake the capitalist order to its foundations. (Keynes 1930 [2008], pp. 1 and 2)

Keynes's key insight was that a market-based, capitalist economy does not possess a self-adjusting mechanism to bring it back to full employment after a negative economic shock. On the contrary, such an economy may remain in a persistent underemployment equilibrium, giving rise to negative expectations, or 'animal spirits', and to a lack of demand for credit, associated with the deleveraging of the private sector. This effectively means that conventional monetary policy measures, such as a reduction in short-term interest rates, do not work. What does? Keynes's answer to this question was a fiscal expansion in aggregate demand through higher government spending and lower direct taxation in order to boost household disposable income.

As we shall see, the Greek crisis has its own particular characteristics, extensively entangled with those of the eurozone construction. However, what distinguishes the public debt crisis in Greece, and indeed in the eurozone, is the fact that the fiscal policy applied goes in the opposite direction to that recommended by such students of the Great Depression as Fisher and Keynes. Austerity, via fiscal consolidation, deregulation and privatization, is the overarching principle of current EU economic policy vis-à-vis indebted countries, such as Greece, as well as on the EU level.

Michal Kalecki's economic and political pragmatism points to a possible reconciliation of this modern-day paradox. In his seminal 1943 article, Kalecki pointed out that a state of permanently high employment would alter power equilibrium within society. However,

[i]n this situation a powerful block is likely to be formed between big business and rentier interests ... The pressure of all these forces and in particular of big business - as a rule influential in Government departments - would most probably induce the Government to return to the orthodox policy of cutting down the budget deficit. (Kalecki 1943, p. 330)

By analogy, it may be argued that the current 'powerful bloc' in the EU, consisting of large, interconnected corporations both in the productive and in the financial sectors, is trying to strengthen its post-crisis position via austerity, even if this means increased damage for themselves at least in the short-run.

\subsection{Greece: from high growth to near insolvency}

Greece, in contrast to many other European countries, did not experience a financial crisis per se. As the financial crisis filtered through to the economy, however, Greece felt the effects of the economic crisis; that is, a decline in output and an increase in unemployment - signs of the oncoming recession - as well as a worsening of its public finances, as the automatic stabilizers came into play.

At the start of the crisis, Greece displayed high public and current-account deficits in relation to GDP, partly explained by the country's high growth rate prior to the crisis and partly by its mode of capitalist formation. 
Table 1 Profiling the Greek economy, 2002-2006 (percentage annual change unless otherwise stated; ranking)

\begin{tabular}{lrrrr}
\hline & EU27 & EU17 & Greece & $\begin{array}{c}\text { Ranking in } \\
\text { EU27; EU17 }\end{array}$ \\
\hline Growth rate & & & & 2.1 \\
Growth rate per capita & 1.7 & 1.2 & 3.3 & 9th; 4th \\
Domestic demand growth & 2.1 & 1.7 & 4.1 & 11th; 4th \\
HICP & 2.3 & 2.2 & 3.4 & 6th; 5th \\
Employment & 0.6 & 0.7 & 1.7 & 8th; 6th \\
Unemployment (\% of labour force) & 8.9 & 8.8 & 9.9 & 6th; 3rd \\
Labour productivity (real GDP per occupied person) & 2.0 & 1.1 & 2.6 & 11th; 4th \\
Real LUC & -1.0 & -0.7 & -0.1 & 9th; 5th \\
Total gen. government expenditure (\% GDP) & 46.7 & 47.4 & 45.2 & 12th; 9th \\
Total gen. government revenue (\% GDP) & 44.2 & 44.8 & 39.3 & 16th; 12th \\
Interest expenditure (\% GDP) & 2.9 & 3.1 & 4.9 & 2nd; 2nd \\
Public deficit cyclically adjusted (\% GDP) & -2.8 & -2.7 & -6.0 & 2nd; 1st \\
Public debt 2006 (\% GDP) & 46.3 & 52.9 & 103.4 & \\
Private debt 2006 (\% GDP) & 123.9 & 140.5 & 93.0 & 16th; 16th \\
Current-account balance (\% GDP) & 0.1 & 0.6 & -11.9 & 3rd; 2nd \\
\hline
\end{tabular}

Sources: European Commission (2011), European Economic Forecast, Autumn and Statistical Annex of European Economy, Autumn; Eurostat.

As shown in Table 1, Greece was a high-performing economy after joining the eurozone and prior to the crisis. Its boom, however, was mainly driven by largely debt-financed domestic demand (public and private). The prevailing low interest rate in the eurozone and the financial deregulation of the EU provided Greece with the means to finance its debt and its current-account deficit. Greece, like Spain and other Southern European states, grew at a faster rate than (for example) Germany, thus providing an outlet for German exports and finance at a time when wage repression in Germany limited domestic demand for goods and services, as well as for loans.

The high public deficit and debt, as well as current account deficit of Greece, are further explained by the country's capitalist formation. More specifically, following a devastating WWII and a destructive civil war (1944-1949), the Greek economy was in a state of collapse. The period 1950-1973 was dominated by the authoritarian Right (1950-1967) and the dictatorship (1967-1973). During this period, economic policy aimed at 'growth at any cost', on the basis of a 'social compromise', which tolerated tax digressions and favourable tax arrangements for the industrial and the shipping sectors, exemption of farmers from income tax, tax evasion by small businesses and professionals, etc. (Stathakis 2010).

The start of the welfare state goes back to the 1980s. Having just joined the European Common Market, Greece underwent a process of deindustrialization. As a result, a number of former national champions were nationalized, with the state taking over their liabilities. The problems facing the economy were compounded by sluggish growth and high inflation, resulting in a severe worsening of public finances. During the period 1950-2010, the question of the elimination of tax evasion remained outside the political agenda. This is a salient feature of the chronic fiscal problems of Greece.

Other features of the Greek economy can be explained by taking a longer-term view of the development of capitalism. For example, the existence of 'closed professions' and high public-sector employment denote the attempts of capitalists to tie in the 
interests of the middle class and sections of the working class to their own. In this sense, the resulting social and economic configuration is a component rather than a symptom of contemporary Greece. ${ }^{9}$

In the wake of the financial crisis, Greek government bonds came under increasing pressure in the financial markets. By April 2010, the spread between the yields on 10 -year Greek government bonds and German bunds became untenable, as shown in Figure 1.

At that point, the available options were:

- Restructuring the Greek public debt. This was indeed quite small by comparison to that of other eurozone member states. ${ }^{10}$ According to the IMF, this option was discussed and rejected by the EU leaders, who feared a possible contagion; that is, an increase in the yields of other Southern European countries' government bonds (IMF 2013). In 2012 the Greek public debt was restructured, albeit through new borrowing.

- The ECB buying up Greek government bonds, as other central banks did at that time vis-à-vis their respective governments. As this is not allowed by the Treaty, the second-best option for the ECB would have been to declare that it was prepared to do 'whatever it takes'. This it did not do until the summer of 2012, when Spain found itself under speculative pressure in the financial markets.

- Greece borrowing from its eurozone partners in order to repay its creditors, that is, the European banks. This is indeed what happened. Two loans were contracted in 2010 and 2012, amounting to a total of $€ 237$ billion, conditional on the implementation of a severe fiscal austerity programme, combined with deregulation and the privatization of public assets and services on a grand scale. Of this amount, more than 80 per cent was channelled back to the European and Greek banks, largely through an over-generous debt restructuring plan (Zettelmeyer et al. 2013).

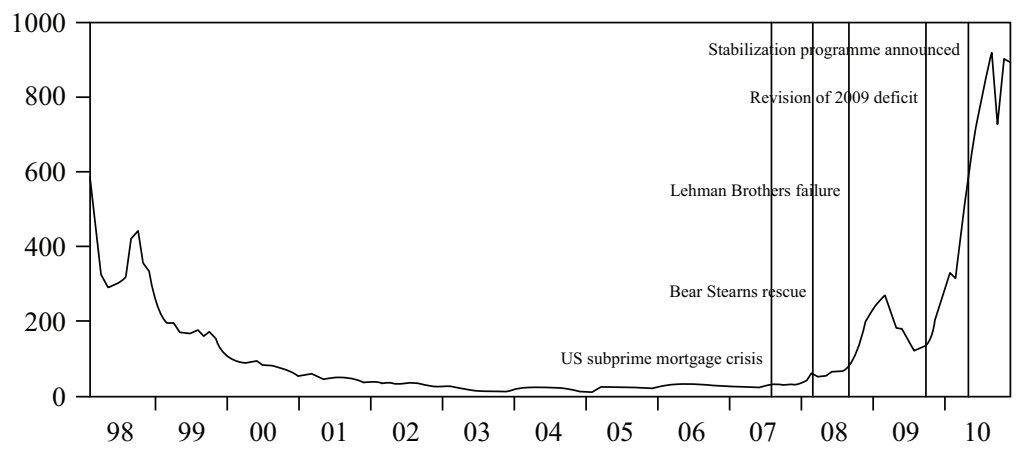

Source: Gibson et al. (2011).

Figure 1 10-year government bond spreads between Greece and Germany

9. See Frangakis (2011) for an account of the Greek public debt crisis.

10. For example, in 2009 it was equal to 5.9 per cent of the combined public debt of France, Germany and Italy (Eurostat annual data). 


\subsection{The Troika prescription}

The austerity measures prescribed by the triumvirate of the European Commission, the European Central Bank and the IMF (alias the Troika) include the following:

- Fiscal consolidation Over the period 2010-2014, fiscal austerity measures amounted to over 30 per cent of GDP, more than half of which (54 per cent) is expected to derive from expenditure cuts and the remainder (46 per cent) from increases in revenue, although only 3 per cent of GDP is to come from improving tax compliance. Public sector employment is being reduced by 23 per cent, while further cuts in spending include education (primary and secondary schools are closed down or merged), health care (hospital units are closed down or privatized, etc.), cash welfare benefits, pensions and social transfers.

- Labour market reforms These aim at reducing the cost of labour via internal devaluation. Thus the minimum wage has been reduced by 22 per cent, and by 32 per cent for the under-25s; collective agreements have been suspended, to be replaced by firm-level agreements; dismissals have been made easier; social contributions have been reduced; life tenure contracts have been abolished. As a result, flexible types of employment are on the rise, even though total employment has been declining. For example, between 2009 and 2013 new hirings declined by 50 per cent, while part-time and temporary hirings increased by more than 50 per cent (INE-GSEE 2013).

- Structural changes These include a far-reaching privatization programme and the deregulation of the transport sector (road haulage), energy (granting access to 40 per cent of lignite-fired capacity before the Public Power Corporation is privatized), the regulated professions (lawyers, public notaries, pharmacists, doctors, etc.), the judicial system and the pension system.

\subsection{From recession to depression}

The Troika prescription intensified the implications of the economic crisis, already discernible in 2009. In effect, it signalled the start of a process of debt-deflation depression of the type experienced in the 1930s. In this section, we shall attempt to disentangle the different aspects of this process and to identify the relevant chain of consequences.

\section{Disinflation and deflation}

The starting point of a debt-deflation is declining prices. Indeed, in Greece, the loss of confidence in the economy led initially to disinflation and, as of late 2012, to deflation. More specifically, the Harmonised Consumer Price Index (HCPI) slowed down from 4.2 per cent in 2008 to 1 per cent in 2012, becoming negative ( -0.9 per cent) in 2013 (Table 2). This downward trend becomes even clearer when energy and seasonal food prices are excluded from the HCPI, which bottomed out at 0 per cent in 2012 and fell to -1.8 per cent in 2013, while the GDP deflator was negative both in 2012 ( -0.3 per cent) and in 2013 ( -2.1 per cent). On the other hand, the price increases observed in 2010 and 2011 were mostly due to the rise in the rate of 
Table 2 Average annual rate of change HCPI (all items) in Greece and the eurozone

\begin{tabular}{lccccccr}
\hline & 2007 & 2008 & 2009 & 2010 & 2011 & 2012 & 2013 \\
\hline Eurozone & 2.1 & 3.3 & 0.3 & 1.6 & 2.7 & 2.5 & 1.4 \\
Greece & 3.0 & 4.2 & 1.3 & 4.7 & 3.1 & 1.0 & -0.9 \\
\hline
\end{tabular}

Source: Eurostat, accessed 21-27 April 2014.

Value Added Tax from 19 per cent to 23 per cent as well as the shifting of many goods and services to a higher-rate bracket. ${ }^{11}$

A disinflationary process is also present in the eurozone on average, although in a milder form, as the HCPI slowed down from 3.3 per cent in 2008 to 1.4 per cent in 2013 as shown in Table 2. Furthermore, the euro currency hardened vis-à-vis that of the EU's main trading partners in the wake of the global financial crisis, thus exacerbating the deflationary dynamics. ${ }^{12}$

\section{Consumption and investment}

As discussed in Section 3.2, prior to the crisis Greece had the highest public debt in relation to GDP, although its ranking with regard to private debt was much lower (Table 1). Thus the decline in prices increased the real value of the debt burden (both public and private). This led households and businesses to reduce their consumption in order to service their debt obligations. Thus, household consumption declined by 4 per cent between 2007 and 2010 and a further 21 per cent between 2010 and 2013, while Gross Fixed Capital Formation fell by 37.2 per cent and 43.6 per cent respectively (Figure 2). At the same time, government consumption was reduced by 6.7 per cent and 15.3 per cent, while government investment declined by 27 per cent and 32 per cent respectively. In other words, faced with the crisis, government policy became highly pro-cyclical. For example, between 2007/2008 and 2012/2013 real public social spending in Greece was reduced by 18 per cent as opposed to an increase of 14 per cent in the OECD and 11 per cent in the EU on average (OECD 2014a).

Furthermore, government revenue was increased mainly through a rise in consumption taxes, the share of which rose from 36.6 per cent of total taxation in 2007 to 38.5 per cent in 2011, far higher than the eurozone average of 27.4 per cent.

\section{Financial distress}

Heightened pressure leads to financial distress and to distress selling. Telling signs of such distress have been the rapid and continuous fall in asset prices. In particular, the House Price Index has been following an inverse trend in relation to the eurozone average since late 2009, as shown in Figure 3.

11. The standard VAT rate applied in Greece is 23 per cent and the reduced rate $6.5-13$ per cent. Greece has one of the highest rates of VAT in the EU, the second-highest gas/petrol tax, and the fifth-highest VAT rate on alcohol.

12. For a comprehensive account of the oscillations of the euro exchange rate, see https:// www.ecb.europa.eu/stats/exchange/effective/html/index.en.html. 


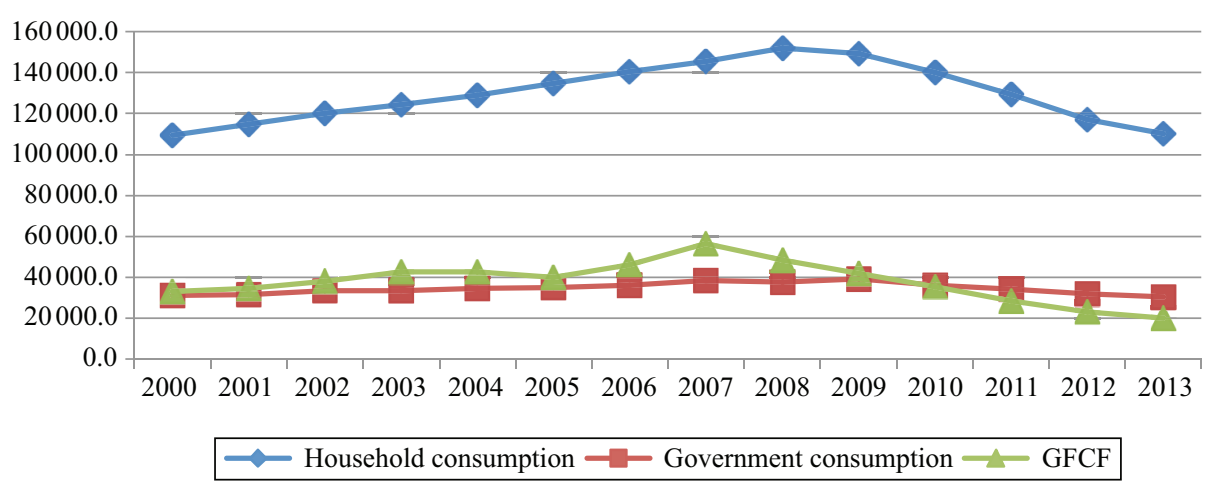

Source: Eurostat, accessed 21-27 April 2014.

Figure 2 GDP components (million euro; 2005 prices)

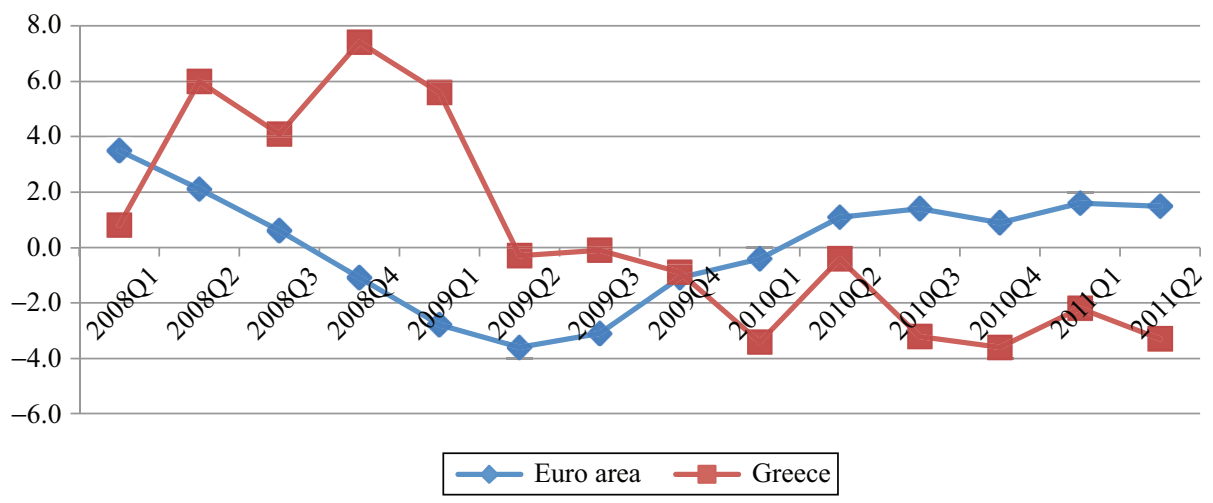

Source: Eurostat, accessed 21-27 April 2014.

Figure 3 House price index - quarterly data, annual rate of change (\%)

The Athens Stock Exchange has also registered steeply declining asset prices. In particular, the ASE Index averaged 1892.83 points from 1987 to 2014, reaching an all-time high of 6.355.04 points in September 1999, dropping to as low as 1032.98 points in December 2014. ${ }^{13}$

The mammoth privatization plan initially included in Greece's Economic Adjustment Programme would have applied even greater pressure on asset prices. The rate of implementation of the plan however has been relatively slow, hinting at possible expectations of further asset price declines.

\section{Bankruptcies}

The decline in asset prices leads to bankruptcies as the net worth of businesses is reduced. Indeed, between 2008 and 2013, 37 per cent of all Greek enterprises closed

13. http://www.tradingeconomics.com/greece/stock-market (accessed 6/12/2014). 
Table 3 Greek SMEs (no of enterprises, million euro GVA, persons employed)

\begin{tabular}{lrrrrrr}
\hline $\begin{array}{l}\text { Enterprises by no of } \\
\text { employees }\end{array}$ & $\begin{array}{c}\text { No of } \\
\text { enterprises }\end{array}$ & GVA & $\begin{array}{c}\text { No of persons } \\
\text { employed }\end{array}$ & $\begin{array}{r}\text { No of } \\
\text { enterprises }\end{array}$ & \multicolumn{2}{c}{$\begin{array}{c}\text { GVA } \\
\text { No of persons } \\
\text { employed }\end{array}$} \\
\hline $0-9$ & 213827 & 5895 & 419600 & 134758 & 4912 & 266436 \\
$10-49$ & 6778 & 3805 & 142890 & 3936 & 2440 & 80274 \\
$50-249$ & 1176 & 4404 & 118250 & 835 & 3173 & 83409 \\
$250+$ & 165 & 7860 & 100286 & 120 & 5845 & 71365 \\
Total & 221946 & 21964 & 781026 & 139649 & 16369 & 501484 \\
\hline
\end{tabular}

Note: GVA $=$ Gross Value Added.

Source: European Commission, Annual Report on European SMEs 2012/2013; database.

down, underlining the severe distress experienced by the Greek economy (European Commission 2013). It should be noted that the vast majority of Greek enterprises are small units (with fewer than 50 employees and mostly family-run), and these were hit especially hard (Table 3 ).

Large, long-established firms have also met with extreme financial difficulties. For example, Nutriart ABEE - created in 2008 from the merger of three of the largest companies in the Greek food industry (Katselis, Allatini and Elvipet) - declared bankruptcy in 2013. Similarly, Greece's biggest furniture company, NEOSET, with a network of 100 stores and 1014 employees, declared bankruptcy in 2012, as did another wellknown Greek furniture manufacturer, SATO ${ }^{14}$

\section{Wages, labour unit costs and gross operating surplus}

The combination of bankruptcies and the drop in aggregate demand has led to a pronounced fall in the wage bill. Between 2008 and 2013, the total compensation of employees declined by 7 per cent on average, while the share of wages in GDP fell from 51.5 per cent in 2006 to 48.8 per cent in 2013, thus returning to its level of the mid 1990s. ${ }^{15}$ Over the same period, gross operating surplus also declined by 3.4 per cent on average, although its share in GDP increased.

As a result, labour unit costs declined steeply in Greece in relation to the eurozone (Figure 4). This is a central objective of the Troika prescription. However, to the extent that the same recipe is followed by all the eurozone member states, its implications for Greek exports are mitigated.

\section{Output and employment}

Between 2007 and 2013, domestic demand declined by 32 per cent. During the same period, exports also declined (by 13 per cent), as did imports (by 43 per cent). Thus,

14. 'One of the largest companies in the food industry declares bankruptcy', 26 June 2013, http://www.grreporter.info, accessed 24 April 2014; 'Greece's biggest furniture company NEOSET files for bankruptcy', 12 November 2011, http://www.keeptalkinggreece.com, accessed 24 April 2014.

15. Compensation per employee as a percentage of GDP at market prices per person employed (AMECO, latest update 5 February 2015). 


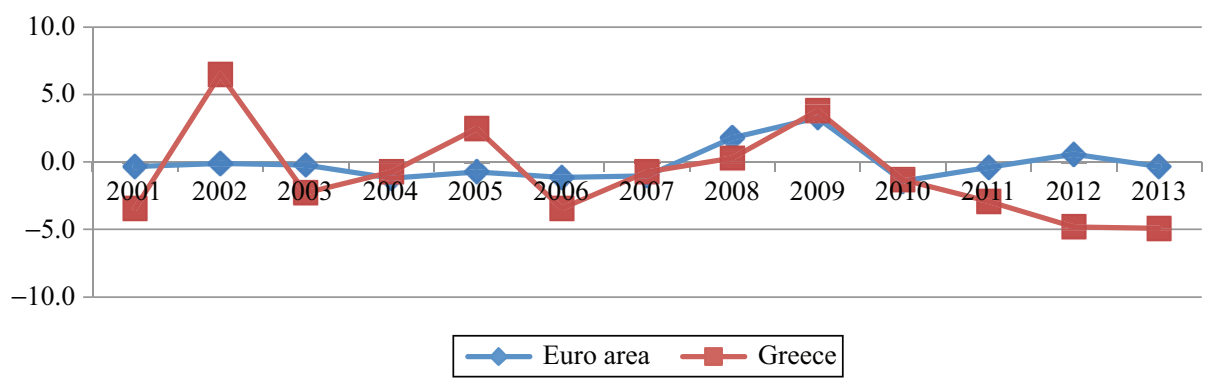

Source: Eurostat, accessed 21-27 April 2014.

Figure 4 Real labour unit cost, percentage change on previous period

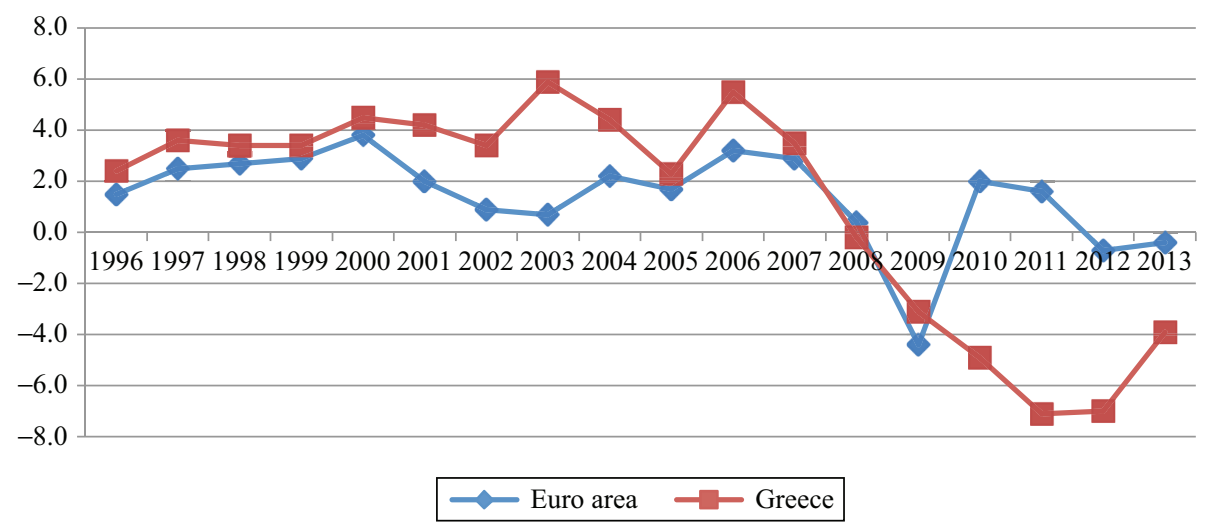

Source: Eurostat, accessed 21-27 April 2014.

Figure 5 GDP at market prices, percentage change on previous year (2005 prices)

although the current-account balance was improved, the gap in domestic demand was not made good.

In fact, output took a deep plunge, far greater than the eurozone average, which is also struggling with a deteriorating growth rate, as shown in Figure 5. In particular, over the period 2007-2013, GDP in Greece declined by nearly 25 per cent in real terms.

Equally striking is the steep rise in the rate of unemployment in Greece, which more than trebled, reaching 27.6 per cent of the labour force in 2013 from 8.3 per cent in 2007. Over the same period, unemployment in the eurozone increased from 7.5 per cent of the labour force in 2007 to 12 per cent in 2013 on average. It is worth noting that unemployment in Greece, as indeed in the EU, has hit female workers and the under-25s especially hard, while long-term unemployment has skyrocketed. For example, 31.6 per cent of female workers and 65 per cent of under-25s were unemployed in 2013, compared to 12.1 per cent and 24 per cent respectively in the eurozone. Furthermore, more than one-third of the unemployed have been without a job for over 1 year.

The social implications of the economic decline signify a rupture in social cohesion. More specifically, between 2007 and 2011, the fall in the disposable income per 
household in Greece was the highest among the 33 member states of the OECD, amounting to 8.3 per cent as opposed to an average fall of 0.50 per cent in the OECD-33 countries (OECD 2014b). Such a decline resulted in greater inequality and poverty, as it hit lower incomes especially hard. For example, in 2012, 34.6 per cent of the population was at risk of poverty or social exclusion, compared to 24.8 per cent in the EU and 23.3 per cent in the eurozone. ${ }^{16}$

\section{Money supply and interest rates}

As pessimism and loss of confidence became entrenched in the Greek economy and society, the hoarding of cash became evident. Thus, by 2012, the sum of total deposits (all types) and currency in circulation (approximating M2) dropped by 25 per cent in relation to 2008, providing a further measure of the collapse of the Greek economy. ${ }^{17}$ Furthermore, bank loans declined by 18 per cent between 2008 and 2012. ${ }^{18}$ On the other hand, nominal interest rates for long-term and short-term lending to non-financial corporations have not declined substantially, oscillating around the 5-6 per cent mark. ${ }^{19}$

\section{Debt}

Although the public deficit declined from 15.2 per cent of GDP in 2009 to 1.6 per cent in 2014, the public debt of Greece has increased both in absolute and in relative terms, as shown in Table $4 .^{20}$

This was the outcome of the loans granted to Greece in 2010 and 2012 and the procyclical austerity policy resulting in the steep contraction of GDP. Not surprisingly, the interest payments paid by Greece to its creditors are much higher than in the EU on average. For example, in 2012 these amounted to 5 per cent of GDP (2012) as opposed to 2.9 per cent in the EU and to 3 per cent in the eurozone. ${ }^{21}$

Table 4 Public debt of Greece 2007-2013

\begin{tabular}{lrrrrrrr}
\hline & 2007 & 2008 & 2009 & 2010 & 2011 & 2012 & 2013 \\
\hline Euros, billion & 239.5 & 263.3 & 299.7 & 329.5 & 355.1 & 303.9 & 322.2 \\
Per cent GDP & 107.3 & 112.9 & 129.7 & 148.3 & 170.3 & 156.9 & 176.2 \\
\hline
\end{tabular}

Source: Eurostat, accessed 21-27 April 2014.

16. http://epp.eurostat.ec.europa.eu/statistics_explained/index.php/People_at_risk_of_ poverty_or_social_exclusion.

17. IMF International Financial Statistics: euro millions, national residency, $34 \mathrm{AZK}+34 \mathrm{ZK}+$ $35 \mathrm{ZK}$.

18. Outstanding amounts of loans and receivables at end period: consolidated banking data, ECB Statistical Data Warehouse.

19. ECB Statistical Data Warehouse, Monetary and Financial Statistics.

20. Excluding interest payments turns a deficit of 10.2 per cent of GDP in 2009 to a government surplus equal to 2.7 per cent of GDP in 2014.

21. The Troika loans were granted on commercial terms. For example, the interest rate on the 2010 loan amounted to 5 per cent p.a. This was reduced to 2 per cent by the end of 2012, which also applied to the 2012 loan. 
Private sector debt has also risen, from 101 per cent of GDP in 2007 to 136 per cent in 2013. ${ }^{22}$ The pressure the private sector finds itself under is further evidenced from the high ratio of non-performing loans (NPL) to GDP. ${ }^{23}$ For example, between Q42008 and Q32013, the ratio of NPL to total gross loans increased from 4.7 per cent to 31 per cent. This was the highest ratio amongst the eurozone member states. ${ }^{24}$

\section{Financial liabilities}

De Grauwe has argued that the fiscal profligacy narrative and the ensuing austerity policy in the eurozone are fighting the 'wrong enemy' (De Grauwe 2010). This is true also of Greece, in spite of its chronically high public deficit and debt. As shown in Figure 6, prior to the financial crisis the ratio of corporate (both financial and non-financial) debt to GDP exceeded that of the public sector, while household debt was also on the rise. It is only after the start of the crisis that public liabilities overtook private ones, with the exception of the financial sector, whose debt continued its upward climb, reflecting the weakening of the economy and the sector's increasing fragility.

Overall, the public debt of Greece remains unsustainable largely due to the debtdeflation dynamics triggered by the economic crisis and amplified by the Troika prescription. Indeed, Papadimitriou et al. have concluded that:

The current economic conditions in Greece are, by and large, the result of foolish policy based on a shaky economic theory that advocates 'expansionary austerity,' along with labor market reforms, as the best recipe for medium- and long-term growth in countries that like Greece are running large government deficits and high levels of public debt as a percentage of GDP. (Papadimitriou et al. 2013, p. 2)

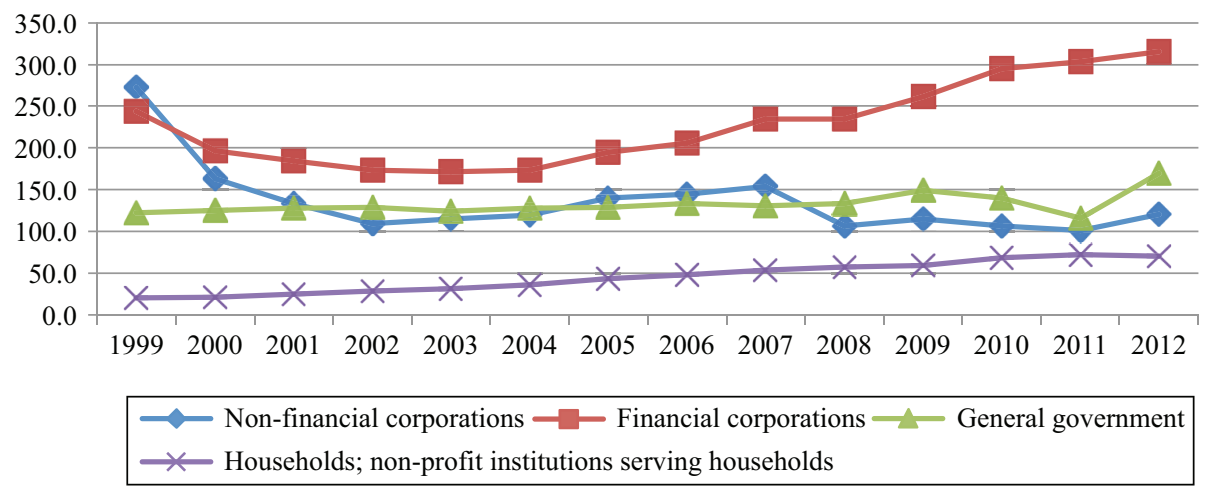

Source: Eurostat, accessed 21-27 April 2014.

Figure 6 Debt by sector as a percentage of GDP

22. Where the private sector debt is the stock of liabilities (Debt securities and Loans at the end of the year) held by Non-Financial corporations and Households and Non-Profit institutions serving households.

23. A loan is non-performing when payments of interest and principal are past due by 90 days or more, in accordance with the Basel II definition of default.

24. http://www.oecd-ilibrary.org/economics. 


\section{EPILOGUE}

The roots of the public debt crisis in Greece go beyond the domestic factors accounting for its high public and current-account deficits. They encompass the narrow outlook of EU policy, which at a time of crisis became highly pro-cyclical, and the role of global finance, of which European finance is an integral part, both in deflecting the pressures for financial policy reform and in shaping economic policy.

Starting in late 2009, the management of the public debt crisis, both by the European and the Greek elites, plunged the economy and large sections of the population into an unprecedented crisis by the standards of a European democracy at a time of peace. This bears many of the characteristics of a debt-deflation depression with the attendant economic and social implications. As Floyd Norris (2013) has observed, 'Seen from Greece, the Great Depression looks good'!

Starting from a high debt level, the Greek economy went through disinflation and deflation, contraction of consumption and investment, distress selling and a fall in asset prices, bankruptcies and a decline in output and employment, while exports did not provide any counter-stimulus. The money supply contracted, as did bank credit.

Five years into the crisis (2009-2014), Greece finds itself in a deflationary process. The prevailing EU policy view supports fiscal austerity and market deregulation as the way out of the crisis. We have argued that this view is based on a theoretical misconception of the crisis, largely explained by an ideological bias against inflation.

The Greek case serves as an illustration of the failure of the current economic and political orthodoxy in the EU. As the recession deepens, morphing into a depression, the outlook for Greece is particularly uncertain. Its eurozone partners seem prepared to provide more concessions in order to keep it in the monetary union, on condition that it continues to apply the Troika prescription. The majority of the Greek people, however, are exhausted by these policies. There have been signs of fascism raising its ugly head in Greece. These have temporarily been stemmed, although in no way eradicated.

The result of the national elections on 25 January 2015 bear witness to the search for an alternative route out of the crisis, a route that makes economic sense and allows the Greek people to maintain their dignity as a democratic polity. SYRIZA (acronym for Coalition of the Radical Left) won 36.34 per cent of the vote, thus forming a government in coalition with the Independent Greeks (ANEL, a centre-right party). SYRIZA's electoral programme prioritized dealing with the humanitarian crisis and undertaking deeply needed reforms, such as eradicating tax evasion and corruption. With regard to the country's mounting public debt, the SYRIZA-led government seeks a solution that will provide some room for fiscal manoeuvre aiming at stimulating the economy and setting it on the path of growth.

So, what is to be done? At the time of writing, the SYRIZA-led government representatives are trying to convince their eurozone partners that the Economic Adjustment Programme of Greece needs to be revised, so as to allow the country to change course and in so doing to reduce its debt. They are also referring to the precedent of the London Debt Agreement of 1953, which forgave the largest part of the debt of Germany, both private and public, incurred in the interwar years and after the Second World War.

These are difficult negotiations insofar as the Greek government is effectively questioning the very edifice on which the present EU orthodoxy is based. In spite of the professed desire of Germany and other eurozone partners to avoid Greece's departure from the European Monetary Union, such an 'accident' cannot be precluded. In fact, SYRIZA's programme does include such a possibility as a last resort. Damaging as 
such an outcome would be for both sides, it may eventually be the only way out of the present impasse.

While the Greek plight does not seem to have influenced EU policy-making so far, the prospect of deflation taking hold of the eurozone seems to be worrying financial analysts, journalists and politicians alike. Quantitative easing, the ECB's 'bazooka', is set against a background of a persistently falling inflation rate in the eurozone, which averaged 0.17 per cent in December 2014 by comparison to 0.85 per cent in December 2013 and 2.22 per cent in December 2012. Although such a measure goes in the direction of easing some of the pressure on the economy, historical experience teaches us that it cannot alone deal with the prospect of deflation. It needs to be matched with fiscal policy, above and beyond the theoretical, ideological and political constraints of eurozone austerity policy.

Furthermore, in a long-run perspective, both the EU and its member states need to adopt policies for the restructuring of their productive sectors, not through further liberalization, but through carefully targeted actions for a socially and environmentally sustainable pattern of development.

\section{REFERENCES}

De Grauwe, P. (2010), 'Fighting the wrong enemy', VOX, 19 May.

European Commission (2012), European Financial Stability and Integration Report.

European Commission (2013), 'A recovery on the horizon?' Annual Report on European SMEs 2012/2013.

European Commission (2014), 'European Economic Forecast: Autumn 2014', European Economy $7 / 2014$.

Fisher, I. (1933), 'The debt-deflation theory of great depressions', Econometrica, 1(4), 337-357.

Frangakis, M. (2006), 'Integrated guidelines for growth and jobs, 2005-2008: a shift in EU economic policy?', European Journal of Economics and Economic Policies: Intervention, 3(1), 59-75.

Frangakis, M. (2011), 'The public debt crisis in Greece - roots, policies, outlook and alternatives', http://www.tni.org/article/public-debt-crisis-greece.

Gibson, H.D., S.G. Hall and G.S. Tavlas (2011), 'The Greek financial crisis - growing imbalances and sovereign spreads', Bank of Greece, WP 124, March.

Grahl, J. (ed.) (2009), Global Finance and Social Europe, Cheltenham, UK and Northampton, MA: Edward Elgar.

IMF (2013), Country Report 13/156, June.

INE-GSEE (Labour Institute of the Confederation of Greek Workers) (2013), Annual Report (in Greek).

Kalecki, M. (1943), 'Political aspects of full employment', The Political Quarterly, 14(4), 322-331.

Keynes, J.M. (1930 [2008]), 'The great slump of 1930', The Nation \& Athenaeum, London, 20 and 27 December, reprinted as an eBook by A Project Gutenberg Canada eBook, 2008, November.

Keynes, J.M. (1936 [2003]), 'Interest and money', The General Theory of Employment, Interest and Money, reprinted as an eBook by A Project Gutenberg Australia eBook, 2003, February.

Norris, F. (2013), 'Seen from Greece, the Great Depression looks good', The New York Times, 16 March.

OECD (2014a), 'Greece', Society at a Glance.

OECD (2014b), 'Income inequality update, rising inequality: youth and poor fall further behind', June.

Palley, T., L.-P. Rochon and M. Vernengo (2012), 'Statement of the co-editors: economics and the economic crisis - the case for change', Review of Keynesian Economics, Inaugural Issue, $1-4$. 
Papadimitriou, D.B., M. Nikiforos and G. Zezza (2013), 'The Greek economic crisis and the experience of austerity: a strategic analysis', Levy Institute of Bard College, Strategic Analysis series, July.

Schauble, W. (2011), 'Why austerity is only cure for the Eurozone', Financial Times, 5 September.

Schiaffino, P. (2013), 'A comment on the ECB solution vs the Keynes solution', Journal of Post Keynesian Economics, 35(3), 457-462.

Stathakis, G. (2010), 'The fiscal crisis of the Greek economy', Paper presented at the IIPPE Conference, September.

Stockhammer, E. (2012), 'Euro-Keynesianism? The financial crisis in Europe', Radical Philosophy, 175, 2-10.

Zettelmeyer, J., Ch. Trebesch and M. Gulati (2013), 'The Greek debt restructuring - an autopsy', Peterson Institute for International Economics, WP 13-8, August. 